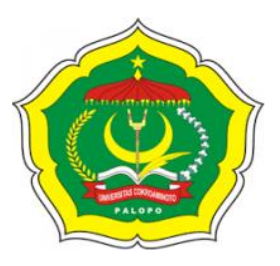

Biogenerasi Vol 6 No 1, Maret 2021

\author{
Biogenerasi \\ Jurnal Pendidikan Biologi \\ https://e-journal.my.id/biogenerasi
}

\title{
ANALISIS KEPRAKTISAN INSTRUMEN PENILAIAN AUTENTIK MATERI EKOSISTEM DI SMA DITINJAU DARI ASPEK PENGGUNA
}

\author{
Dian Dwi Putri Ulan Sari Patongai, Universitas Negeri Makassar, Indonesia \\ Saparuddin, Universitas Negeri Makassar, Indonesia \\ Sahribulan, Universitas Negeri Makassar, Indonesia \\ *Corresponding author E-mail: dianputriulan@unm.ac.id
}

\begin{abstract}
:
This study aims to analyze the practicality of an authentic assessment instrument for ecosystem materials in high school which has been developed using the 4D development model (Define, Design, Development, Disseminate) by Thiagarajan. The practicality of the instrument in terms of the user aspect is measured using a teacher response questionnaire filled out by the teacher and also students who are given an assessment instrument to use. Aspects assessed in the instrument are related to aspects of clarity and aspects of understanding/acceptance. Practically, teachers find it easy to use it in assessing student learning outcomes and students who feel enthusiastic about learning that apply authentic assessment instruments. From the results of data analysis carried out, the teacher gave a very positive response to both aspects which were assessed with a student response value of $92.5 \%$ greater than $85 \%$. Meanwhile, the student response showed that the students gave a positive response to the implementation of authentic assessment of ecosystem materials with a response value of $84.11 \%$. Thus, it can be concluded that the authentic assessment instrument for ecosystem material that has been developed can practically be used properly and gives a positive response from both teachers and students.
\end{abstract}

Keywords: Authentic Assessment, Teacher Response, Student Response

Abstrak

Penelitian ini bertujuan untuk menganalisis kepraktisan instrumen penilaian autentik materi ekosistem di SMA yang telah dikembangkan dengan menggunakan model pengemabangan 4D (Define, Design, Development, Disseminate) oleh Thiagarajan. Kepraktisan instrumen ditinjau dari aspek pengguna diukur dengan menggunakan angket respon guru yang diisi oleh guru dan juga peserta didik yang diberikan instrumen penilaian untuk digunakan. Aspek yang dinilai dalam instrumen terkait aspek kejelasan dan aspek keutuhan pemahaman/ penerimaan. Secara praktis, guru merasa mudah menggunakannya dalam menilai hasil belajar peserta didik serta peserta didik yang merasa antusias dengan pembelajaran yang merapkan isntrumen penilaian autentik. Dari hasil analisis data yang dilakukan, guru memberikan respin yang sangat positif pada kedua aspek yang dinilai dengan nilai respon siswa $92,5 \%$ lebih besar dari $85 \%$. Sedangkan untuk respon siswa menunjukkan bahwa siswa mebberikan respon positif terhadap implementasi penialaian autentik mataeri ekosistem dengan nilai respon 84,11\%. Dengan demikian dapat disimpulkan bahwa Instrumen penilaian autentik materi ekosistem yang telah dikembangkan praktis dapat digunakan dengan baik dan meberikan respon positif baik dari guru maupun dari peserta didik.

Kata Kunci: Penilaian Autentik, Respon Guru, Respon Siswa 


\section{PENDAHULUAN}

Pembelajaran adalah kegiatan yang mencakup proses interaksi peserta didik dengan pendidik dan sumber belajar pada suatu lingkungan belajar (UU No. $20 \mathrm{Th}$ 2003). Proses pembelajar mencakup tiga aspek penting yang harus dilalui yaitu aspek perencanaan, pelaksanaan dan juga evaluasi atau penilaian. Perencanan pembelajaran menrupakan Langkah awal dalam menusun sebauh pembelajaran yang didalamnya mencakup tentang pemilihan metode, media, penysunan Langkah Langkah pembelajara hingga rencana penugasan dan penilaian. Semua poin tersebut dimasukkan dalam satu dokemn yang dikenal dengan istilah Rencana Pelaksannaan Pembelajaran (RPP). Tahapan selajutnya adalah pelaksanaan, pembelajaran dilaksanakan sesuai perencanaan yang telah disusun sebelumnya. Dan tahap terakhir adalah evaluasi yang merupakan tahap ketiga dari proses pembelajaran.

Evaluasi yaitu suatu kegiatan yang dilakukan untuk mengukur keberhasilan suatu program dalam hal ini program pembelajaran.. Melalui proses evaluasi dapat diperoleh berbagai informasi tentang apa saja yang telah dicapai dan belum tercapai yang selanjutnya informasi tersebut digunakan untuk perbaikan suatu pembelajaran. (Mardapi, 2012).

Evaluasi dan penilaian peserta didik dalam mencapai tujuan yang diharapkan hendaknya dilakukan dengan seobjektif mungkin dan secara menyeluruh, artinya, tidak hanya berfokus pada hasil tetapi juga menilai keseluruhan proses pembelajaran. Salah satu bentuk penilaian yang dapat mengakomodir penilaian hasil dan proses pembelajaran adalah penilaian autentik.

Penilaian autentik merupakan penilaian yang dilakukan secara holistic yang tidak hanya berfokus pada hasil pembelajaran pada akhir masa belajar tetapi juga menilaia proses pembelajaran. Selain itu penilaian autentik juga tidak hanya menilai aspek kognitif tatapi juga aspek psikomotorik dan aspek afektif. Wildan (2017) menyatakan Penilaian autentik juga diartikan sebagai proses pengumpulan informasi oleh guru tentang perkembangan dan pencapaian pembelajaran yang dilakukan anak didik melalui berbagai teknik yang mampu mengungkapkan, membuktikan atau menunjukkan secara tepat pada tujuan pembelajaran dan kemampuan (kompetensi) telah benarbenar dikuasai dan dicapai.

Penilaian autentik

memiliki relevansi terhadap pendekatan ilmiah dalam pembelajaran sesuai dengan tuntutan Kurikulum 2013. Penilaian tersebut dapat menggambarkan peningkatan hasil belajar peserta didik, baik dalam rangka mengobservasi, menalar, mencoba, membangun jejaring, dan lainlain. Penilaian autentik fokus pada tugastugas kompleks atau kontekstual yang memungkinkan peserta didik untuk menunjukkan berbagai kompetensi mereka dalam pembelajaran yang lebih autentik (Badan Pengembangan Sumber Daya Manusia Pendidikan dan Kebudayaan dan Penjamin Mutu Pendidikan, 2013).

Penelitian yang dilakukan oleh Ari Astriyandi dkk (2016) menunjukkan bahwa Kemampuan guru dalam menerapkan penilaian autentik dinilai kurang, dibuktikan dengan tidak adanya rubrik penilaian dari instrument yang telah dibuat oleh guru yakni instrument penilaian sikap dan keterampilan, serta guru mengalami kesulitan dalam membuat kriteria atau rubrik penilaian dan juga instrument penilaian autentik. Hal ini sejalan dengan hasil observasi yang telah dilakukan oleh penulis, menunjukkan bahwa beberapa guru masih belum memahami dengan baik bagaimana prosedur penilaian autentik. Oleh karenya perlu dikembangkan instrument penilaian autentik beserta panduan penilaian yang dapat digunakan 
oleh guru dalam melaksanakan penilaian autentik kepada peserta didik.

Penilaian autentik mencakup penilaian diranah afektif,kognitif dan psikomotirik sehingga memerlukan instrumen penilaian yang lebih kompleks dibandingka penilaian lain.instumen penilaian autentik perlu dikembangkan sebaik mungkin agar dapat mengukur apa yang sebaiknya diukur. Selain itu, melihat kompleksitas dari penilaian autentik, perlu dikembangkan instrumen penilaian yang selain layak digunakan juga praktis digunakan bagi pengguna dalam hal ini guru. Penelitian ini merupakan penelitian lanjutan dari pengambangan instrumen penilaian autentik materi ekosistem di SMA, dimana pada penelitian sebelumnya telah dikembangkan dan diuji kelayakan instrumen. Selanjutnya dalam penelitian ini, instrumen yang dikembangkan di uji kepraktisannya bagi pengguna dengan melihat respon dari guru maupun siswa terkait implementasi penilaian autentik sebagai alat evaluasi pembelajaran.

\section{METODE}

Metode penelitian yang digunakan dalam penelitian ini adalah metode servey dengan menggunakan angket. Angket yang digunakan terdiri atas dua jenis yakni angket respon guru dan juga angket respon siswa. Angket respon guru disusun untuk memperoleh informasi mengenai tanggapan guru sebagai pengguna instrumen penilaian autentik. Angket yang digunakan berisikan pertanyaan mengenai dua aspek penting dalam pengembangan isntrumen penilaian, yakni aspek kejelasan dan aspek keutuhan pemahaman/penerimaan yang seluruhnya terdiri atas 10 Item pernyataan. Untuk angket respon siswa terdiri atas delapan item pernyataan mengenai penerapan instrumen penilaian autentik yang dikembangkan.

Populasi dalam penelitian ini adalah seluruh guru biologi di SMA Negeri 1 Bulukumba yang berjumlah 6 Orang dan juga peserta didik kelas X MIA I SMA Negeri 1 Bulukumba yang berjumlah 36 orang sebagai responden untuk angket respon siswa.

Angket respon guru disebar kepada 5 orang responden yang merupakan pengguna instrumen dalam hal ini guru biologi pada lokasi penyebaran instrumen. Nilai yang diberikan guru terhadap setiap item kemudian direkapitulasi dan dirataratakan . untuk angket respon siswa diberikan kepada 36 peserta didik yang menjadi objek uji coba instrumen.

Teknik analisis data yang digunakan adalah analisis deskriptif yaitu dengan mendeskripsikan data yang telah diperoleh setelah seluruh responden yang dituju mengisi angket, setelah itu menyimpulkan kepraktisan instrumen berdasarkan kriteria kepraktisan yang telah ditentukan.

Menentukan kategori respon yang diberikan guru terhadap suatu kriteria dengan cara mencocokkan hasil persentase dengan kriteria positif menurut Khabibag (dalam Yamasari) dengan modifikasi pada kriterianya, yaitu

Tabel 2.1 Kategori Respon Pengguna

\begin{tabular}{|l|l|}
\hline Persentasi & Kategori \\
\hline $85 \% \leq \mathrm{RP}$ & Sangat Positif \\
\hline $75 \% \leq \mathrm{RP}<85 \%$ & Positif \\
\hline $50 \% \leq \mathrm{RP}<75 \%$ & Kurang Positif \\
\hline $\mathrm{RP}<50 \%$ & Tidak Positif \\
\hline
\end{tabular}

Sumber : Yasmasari (2010) 


\section{HASIL DAN PEMBAHASAN}

\section{Hasil Penelitian}

Data angket yang telah diisi oleh pengguna, dalam hal ini guru selanjutnya dianalisis secara deskriptif untuk menemukan gambaran penilaian pengguna. Data responden dianalisis berdasarkan

indikator kejelasan dan juga keutuhan pemahaman/penerimaan. Hasil penelitian disajikan dalam tabel 3.1 dan tabel 3.2 berikut ini.

Tabel 3.1 Tabel Analisis Respon Guru Aspek Kejelasan

\begin{tabular}{|c|c|c|c|c|c|c|c|c|c|c|}
\hline \multirow[t]{2}{*}{$\mathrm{No}$} & \multirow[t]{2}{*}{ Pernyataan } & \multicolumn{6}{|c|}{ Responden } & \multirow{2}{*}{$\begin{array}{l}\text { Skor } \\
\text { Total }\end{array}$} & \multirow{2}{*}{$\begin{array}{l}\text { Konversi } \\
\text { Skor }(\%)\end{array}$} & \multirow{2}{*}{$\begin{array}{l}\text { Rerata } \\
\text { Keseluruhan } \\
\text { Indikator }\end{array}$} \\
\hline & & 1 & 2 & 3 & 4 & 5 & 6 & & & \\
\hline 1 & $\begin{array}{l}\text { Pedoman dan instrumen } \\
\text { penilaian menggunakan } \\
\text { Bahasa yang jelas dan } \\
\text { mudah dimengerti }\end{array}$ & 4 & 4 & 4 & 4 & 4 & 4 & 24 & 100 & \\
\hline 2 & $\begin{array}{l}\text { Penilaian Aspek } \\
\text { Psikomotrik, Afektif dan } \\
\text { Kognitif tergambar dengan } \\
\text { jelas }\end{array}$ & 4 & 4 & 4 & 4 & 4 & 4 & 24 & 100 & \\
\hline 3 & $\begin{array}{l}\text { Penilaain Psikomotorik } \\
\text { dalam instrumen mencakup } \\
\text { beberapa bentuk penilaian } \\
\text { yang dibutuhkan }\end{array}$ & 4 & 4 & 4 & 4 & 4 & 3 & 23 & 95,8 & $95,8 \%$ \\
\hline 4 & $\begin{array}{l}\text { Instrumen penilaian } \\
\text { bersesusian dengan RPP dan } \\
\text { Silabus }\end{array}$ & 3 & 4 & 4 & 4 & 4 & 4 & 23 & 95,8 & \\
\hline 5 & $\begin{array}{l}\text { Rubrik bersesuaian dengan } \\
\text { aspek yang akan diukur }\end{array}$ & 4 & 3 & 4 & 4 & 3 & 3 & 21 & 87,5 & \\
\hline
\end{tabular}

Tabel 3.1 diatas menunjukkan respon guru terhadap instrumen penilaian autentik pada aspek kejelasan. Nilai maksimum setiap pernyataan pada angket adalah 4 dan nilai minimum adalah 1 . Sehingga nilai maksimum keseluruhan untuk 6 responden pada setiap indikator adalah 24. Hasil angket menunjukkan untuk Indikator pertama mengenai penggunaan Bahasa pada pedoman instrumen dan pedoman penilaian autentik yang dikembangkan secara jelas, dari 6 responden membrikan skor memberikan skor maksimal. Begitupun dengan indikator kedua mengenai penggabmaran ketiga aspek (aspek psikomotorik, afektif dan kognitif) dalam instrumen penilaian autentik juga memperoleh skor maksimal dari keenam responden. Untuk indikator kelima mengenai kesesuaian rubrik dengan aspek yang akan diukur, 3 responden memberikan skor maksimal dan 3 lainnya memberikan skor 3, sehinga skor totalnya $87,5 \%$. Secara keseluruhan, rerata skor untuk aspek kejelasan yang terdiri dari lima indikator adalah $95,8 \%$. 
Tabel 3.2 Tabel Analisis Respon Guru Aspek Keutuhan Pemahaman/Penerimaan

\begin{tabular}{|l|l|l|l|l|l|l|l|l|l|l|}
\hline No & Pernyataan & $\mathbf{6}$ & $\mathbf{2}$ & $\mathbf{3}$ & $\mathbf{4}$ & $\mathbf{5}$ & $\mathbf{6}$ & Total & $\begin{array}{l}\text { Konversi } \\
\text { Skor (\%) }\end{array}$ & $\begin{array}{l}\text { Rerata } \\
\text { Keseluruhan } \\
\text { Indikator }\end{array}$ \\
\hline $\mathbf{1}$ & $\begin{array}{l}\text { Pengaplikasian Instrumen } \\
\text { penilaian autentik pada } \\
\text { peserta didik sangat praktis } \\
\text { dan mudah }\end{array}$ & 4 & 4 & 4 & 4 & 4 & 3 & 23 & 95,75 & \\
\hline $\mathbf{2}$ & $\begin{array}{l}\text { Lembar observasi pada } \\
\text { penilaian autentik mudah } \\
\text { dipahami }\end{array}$ & 4 & 4 & 4 & 3 & 3 & 4 & 22 & 91,75 & \\
\hline $\mathbf{3}$ & $\begin{array}{l}\text { Kriteria/aspek penilaian } \\
\text { dapat diamati sehingga } \\
\text { rubrik penilaiannya dapat } \\
\text { saya kembangkan }\end{array}$ & 4 & 4 & 3 & 4 & 4 & 4 & 23 & 95,75 & \multirow{2}{*}{$\mathbf{9 2 , 5 \%}$} \\
\hline $\mathbf{4}$ & $\begin{array}{l}\text { Rubrik penilaiannya } \\
\text { praktis dan mudah } \\
\text { digunakan }\end{array}$ & 4 & 3 & 4 & 4 & 3 & 3 & 21 & 87,5 & \\
\hline $\mathbf{5}$ & $\begin{array}{l}\text { Contoh perhitungan skor } \\
\text { pada buku pedoman } \\
\text { penilaian autentik mudah } \\
\text { dipahami }\end{array}$ & 4 & 4 & 4 & 4 & 3 & 3 & 23 & 91,75 & \\
\hline
\end{tabular}

Tabel 3.2 diatas menunjukkan respon guru terhadap instrumen penilaian autentik pada aspek Keutuhan pemahaman/penerimaan. Terdapat lima indikator yang dinilai oleh pengguna yaitu kemudahan pengaplikasian instrumen penilaian autentik yang dikembangkan, Kemudahan dalam memahami lembar observasi pada penilaian autentik serta pedomen penilaian, kesanggupan mengembangkan kriteria penilaian berdasarkan rubrik, kemudahan dan kepraktisan rubrik penilaian serta keudahan dalam memahami contoh perhitungan skor pada buku pedoman.
Nilai maksimum setiap pernyataan pada angket adalah 4 dan nilai minimum adalah 1 . Sehingga nilai maksimum keseluruhan untuk 6 responden pada setiap indikator adalah 24. Hasil angket menunjukkan skor untuk Indikator pertama dari 6 responden adalah $95,75 \%$ dari nilai maksimal $100 \%$. Untuk indikator kedua memperoleh skor total 91,75 , indikator ketiga 95,75 , indikator keempat 87,5 dan indikator kelima 91,75. Secara keseluruhan rerata untuk aspek Keutuhan pemahaman/penerimaan oleh pengguna adalah sebesar $92,5 \%$.

Tabel 3.3 Pengkategorian Respon Guru terhadap Instrumen Penilaian Autentik

\begin{tabular}{|l|l|l|l|}
\hline No & Aspek & Rerata Nilai & Kategori \\
\hline 1 & Kejelasan & $95,8 \%$ & Sangat Positif \\
\hline 2 & $\begin{array}{l}\text { Keutuhan } \\
\text { Pemahaman/Penerimaan }\end{array}$ & $92,5 \%$ & Sangat Positif. \\
\hline
\end{tabular}

Tabel 3.3 menunjukkan pengkategorian respon guru yang dikelompokkan dalam empat kategori yaitu Sangat positif, positif, kurang positif dan tidak positif berdasarkan tabel pengkategorian 2.1. Hasil pengkategorian menunjukkan respon siswa pada kedua aspek lebih besar dari $85 \%$ yang menunjukkan bahwa pengguna atau guru menunjukkan respon sangat positif terhadap instrumen penilaian yang dikembangkan.

Selain angket respon guru, dalam menguji kepraktisan instrument juga digunakan angket respon siswa yang hasilnya terlihat dalam tabel 3.4 berikut ini. 
Tabel 3.4 Respon Siswa terhadap Instrumen Penilaian Autentik

\begin{tabular}{|c|c|c|c|c|c|c|c|}
\hline \multirow[t]{2}{*}{ No } & \multirow{2}{*}{ Aspek Yang dinilai } & \multicolumn{4}{|c|}{ Kriteria } & \multirow{2}{*}{$\begin{array}{l}\text { Total } \\
\text { skor }\end{array}$} & \multirow{2}{*}{\begin{tabular}{|l} 
Total \\
konversi \\
nilai respon \\
siswa
\end{tabular}} \\
\hline & & STS & TS & $\mathrm{S}$ & SS & & \\
\hline 1 & $\begin{array}{l}\text { Saya memahami tentang penilaian } \\
\text { autentik }\end{array}$ & 0 & 1 & 5 & 30 & 136 & $95,1 \%$ \\
\hline 2 & $\begin{array}{l}\text { Saya lebih senang dinilai secara } \\
\text { menyeluruh dengan penilaian } \\
\text { autentik }\end{array}$ & 1 & 3 & 6 & 26 & 129 & $89,6 \%$ \\
\hline 3 & $\begin{array}{l}\text { Penialain autentik memberikan } \\
\text { penialaian yang adil kepada seluruh } \\
\text { peserta didik }\end{array}$ & 2 & 2 & 8 & 24 & 126 & $87,5 \%$ \\
\hline 4 & $\begin{array}{l}\text { Saya merasa termotivasi untuk } \\
\text { belajar lebih giat dengan adanya } \\
\text { penilaian autentik }\end{array}$ & 1 & 4 & 7 & 24 & 126 & $87,5 \%$ \\
\hline 5 & $\begin{array}{l}\text { Saya merasa penilaian autentik } \\
\text { yang dilakukan dapat menilai sikap } \\
\text { dan keterampialn dengan baik }\end{array}$ & 4 & 4 & 8 & 20 & 116 & $80,6 \%$ \\
\hline 6 & $\begin{array}{l}\text { Saya merasa intrumen penilaian } \\
\text { yang jelas dapat memberikan } \\
\text { penilaian yang objektif }\end{array}$ & 2 & 2 & 14 & 18 & 106 & $83,3 \%$ \\
\hline 7 & $\begin{array}{l}\text { Tidak sulit melalui } \begin{array}{r}\text { proses } \\
\text { pembelajaran }\end{array} \\
\text { diterapkannya penialain autentik }\end{array}$ & 6 & 8 & 10 & 12 & 100 & $69,4 \%$ \\
\hline 8 & $\begin{array}{lcr}\text { Antusiasme terhadap } & \text { proses } \\
\text { pembelajaran meningkat } & \text { dengan } \\
\text { adanya penilaian autentik } & \end{array}$ & 3 & 6 & 8 & 19 & 115 & $79,9 \%$ \\
\hline & Total & & & & & & $84,11 \%$ \\
\hline
\end{tabular}

Angket respon siswa terdiri atas 8 item peryataan positif dengan skala penilaian 1-4 dengan skor maksimum 4 . Indikator penilaian yang tercantum pada angket meliputi pemahaman terhadap penilaian autentik, peningkatan motivasi dan minat belajar, respon mengenai objektifitas penialian, kesulitan dalam penerapan kaitannya dengan pembelajaran serta antusiasme terhadap pembelajaran dengan penerapan penalaian autentik. $50 \%$ penyataan memperoleh skor diatas $85 \%$ dan $50 \%$ lainnya dibawah $85 \%$. Secara keseluruhan respon siswa setelah total skor dikonversi kedalam nilai persen memperoleh nilai $84,11 \%$. Untuk kategori respon siswa sesuai dengan tabel 2.1, dapat disimpulkan bahwa siswa memberikan respon positif terhadap instrumen yang dikembangkan.

\section{Pembahasan}

Berdasarkan analisis data secara deskriptif dapat dilihat bahwa pengguna menunjukkan respon yang sangat positif terhadap aspek kejelasan dan keutuhan pemahaman dan penerimaan dari instrumen yang dikembangkan. Pengguna mernganggap bahwa instrumen yang dikembangkan sudah sangat membantu dan memudahkan dalam melakukan penilaian secara autentik pada peserta didik. Pedoman penilaian yang menjadi bagian dari instrumen penialaian autentik memberikan 
informasi dengan sangat jelas menganai tata cara penilaian.

Selain itu Bahasa yang digunakan dalam pedoman dan instrumen penilaian autentik yang dikembangkan juga dinilai oleh pengguna mudah dipahami dat tidak menimbulkan multitafsir. Aspek penilaian dan juga rubrik bersesuaian dengan Tujuan dan rencana pembelajaran yang tertuang dalam RPP dan juga silabus sehingga instrumen penilaian dapat mengukur apa yang seharusnya diukur dan memenuhi kaidah evaluasi.

Rubrik penilaian menjadi satu bagian yang penting dalam instrumen penilaian yang dikembangkan. Menurut Nuansa Bayu Sagara (2014) Rubrik merupakan alternative assessment yang sangat cocok untuk menilai secara objektif dan terukur untuk kegiatan proses pembelajaran atau produk hasil pembelajaran. Proses pembelajaran dinilai secara autentik berdasarkan kriteria yang ditentukan dalam rubrik. Kriteria dimasukkan dalam rubrik disesuaikan dengan kompetensi dasar yang harus dicapai oleh peserta didik.

Suwarno (2016) mengungkapkan bahwa Rubrik penilaian memberikan manfaat kepada peserta didik, guru dan sekolah. Rubrik memberikan masukan dan umpan balik untuk membantu meningkatkan keterampilan, dan menjadi cara yang ampuh untuk mengklarifikasi tujuan dan keterampilan peserta didik. Kendala-kendala utama adalah dalam perumusan tingkatan indikator-indikator keterampilan yang komprehensip, visibel, dan mudah diamati.oleh karena itu rubrik harus disusun sejelas mungkin dan juga sepraktis mungkin agar memudahkan guru dalam melakukan penilaian yang objektif berdasarkan rubrik. Dari hasil analisis deksriptif yang diperoleh, respon guru terhadap kepraktisan dan kemudahan pemahaman pada rubrik memperoleh respon yang sangat positif, yang artinya guru merasa bahwa rubrik yang dikembangkan Bersama dengan intrumen penilaian autentik sangat praktis dan mudah dipahami dan dapat digunakan secara praktis dalam penilaian.

Penelitian yang dilakukan oleh Hajaroh dan Adawiyah (2018) menunjukkan bahwa salah satu kesulitan dalam menerapkan penilaian autentik adalah mengelolah skor dari masing masing kriteria yang dinilai. Panduan pengelolaan nilai yang juga menjadi bagian dari pedoman penggunaan instrumen penilaain autentik juga mendapatkan respon yang sangat positif dari pengguna karena mudah dipahami.sehingga kesulitan dalam pengelolaan nilai dapat teratasi dengan baik.

Selain respon guru terhadap instrumen penualaian autentik yang dikembangkan, dalam penelitian ini juga digambarkan secara deskriptif bagaimana respon siswa terhadap instrumen penilaian autentik. Secara keseluruhan siswa memberikan respon positif terhadap implementasi instrumen penilaian autentik yang dikembangkan. Sebagian besar peserta didik sangat setuju dengan objektifitas yang dihasilkan oleh penilaian autentik. Peserta didik beranggapan bahwa instrumen penilaian autentik dapat meningkatkan motivasi belajar dan juga minat belajar serta antuasisme terhadap peroses pembelajaran karena penilaian dilakukan secara holistic. Hal ini sejalan dengan penelitian yang dilakukan oleh Neneng Kusmijati (2014) yang menyatakan bahwa penilaian autentik dapat digunakan oleh pendidik dalam memberikan motivasi peserta didik karena hasil dari penilaian yang dilakukan dapat menstimulasi tindakan peserta didik sehingga dapat meningkatkan motivasi belajar peserta didik. Begitupun dengan hasil penelitian yang dilakukan oleh Faiziyyah dan Ghaida (2018) yang menyatakan bahwa penilaian autentik berpengaruh terhadap motivasi belajar peserta didik.

\section{KESIMPULAN DAN SARAN}

\section{Kesimpulan}


Berdasarkan hasil penelitian dan analisis data secara deskriptif menunjukkan bahwa 82nstrument penilaian autentikmateri ekosistem memperoleh respon sangat posisitif dari guru sebagai pengguna dengan nilai repson 92,5\%. Begitupun dengan respon siswa terhadap impelementasi penialain autentik yang dikembangkan yang menunjukkan respon positif dengan nilai respon $84,11 \%$. Dengan demikian dapat disimpulkan bahwa Instrumen penilaian autentik materi ekosistem yang telah dikembangkan praktis dapat digunakan dengan baik dan meberikan respon positif baik dari guru maupun dari peserta didik

\section{Saran}

Instrumen pelilaian autentik perlu dilakukan pembaharuan secara berkala mengingat kemajuan Ilmu Pengetahuan dan teknologi yang berdampak pada kebutuhan masyarakat terhadap lulusan yang menstimulasi adanya perubahan kurikulum. Oleh karenya perlu dilakukan pengembangan instrumen secara berkelanjutan agar pelaksanaan penilaian proses dan hasil pembelajaran dapat tertunjang dengan baik.

\section{DAFTAR PUSTAKA}

Siti Hajaroh dan Raudatul Adawiyah. 2018. Kesulitan guru dalam mengimplementasikan penilaian autentik. El-Midad Jurnal Jurusan PGMI p-ISSN 2087-8389 Vol. 10(2) 2018 Hal. 131-152.

Nuansa Bayu Segara. 2014. Penggunaan rubrik sebagai alternative assessment pada mata kuliah seminar studi sosial. Edunomic | Volume 2 No. 2 Tahun 2014 Hal. 63 -69 .

Suwarno. 2016. Pentingnya Rubrik Penilaian Dalam Penilaian Keterampilan Vocational Siswa. Prosiding Seminar Nasional UNS Vocational

Day.
DOI: https://doi.org/10.20961/uvd .v1i0.7208

Neneng Kusmijati. 2014. Penerapan Penilaian Autentik Sebagai Upaya Memotivasi Belajar Peserta Didik. Prosiding Seminar Nasional Hasil Hasil Penelitian dan Pengabdian LPPM UMP 2014 ISBN 978-60214930-3-8. Purwokerto, Desember2014 Hal. 55- 62.

Fauziyyah, Ghaida Nurul (2018) Pengaruh penilaian autentik dalam kurikulum 2013 terhadap motivasi belajar siswa pada mata pelajaran PAI. Diploma thesis, UIN Sunan Gunung Djati Bandung. http://digilib.uinsgd.ac.id/16842/

Yamasari, Y. 2010, 4 Agustus. Pengembangan Media Pembelajaran Matematika Berbasis ICT yang Berkualitas. Seminar Nasional Pascasarjana X-ITS. ISBN No. 979-545-0270-1. Surabaya

Badan Pengembangan Sumber Daya Manusia Pendidikan dan Kebudayaan dan Penjamin Mutu Pendidikan. 2013. Konsep Penilaian Autentik Pada Proses dan Hasil Belajar. Jakarta: Badan Pengembangan Sumber Daya Manusia Pendidikan dan Kebudayaan dan Penjamin Mutu Pendidikan. Kemendikbud

Direktorat Pembinaan SMA, Ditjen Pendidikan Menengah. 2013. Model Penilaian Hasil BelajarSMA Kurikulum 2013. Kemendikbud

Mardapi, Djemari. 2012. Pengukuran, penilaian, dan evaluasi pendidikan. Yogyakarta: Medica Publishing.

Wildan. 2017. Pelaksanaan Penilaian Autentik Aspek Pengetahuan, Sikap dan Keterampilam di Sekolah atau Madrasah. Jurnal Tatsqif. Jurnal Pemikiran dan Penelitian Pendidikan, Volume 15 No. 2. Desember 2017. 
Ari Astriyandi dkk. 2016. Kemampuan guru menerapkan penilaian autentik dalam pembelajaran PPKN (studi kasus di SMA Negeri 1 indralaya). JURNAL BHINNEKA TUNGGAL IKA, VOLUME 3, NOMOR 2, NOVEMBER 2016. 